\title{
Evolution of the Apollo-Soyuz Test Project: The Effects of the "Third" on the Interplay Between Cooperation and Competition
}

\author{
Darina Volf ${ }^{1}$ (iD
}

Accepted: 13 January 2021 / Published online: 9 February 2021

(C) The Author(s) 2021

\begin{abstract}
The paper investigates the evolution of the first manned international space mission - a rendezvous and docking between a US and a Soviet spacecraft in 1975 known as the Apollo-Soyuz Test Project (ASTP). The aim is to reconsider the rationales behind the ASTP from both a conceptual and an empirical perspective in order to get a better understanding of the evolution of international cooperation in the highly competitive and strategic field of space technology. Based on archival sources from Moscow, it sheds some light on those factors that led to a change in the previous reluctance of Soviets to cooperate with the US in the manned spaceflight. From the theoretical point of view, it argues that the ASTP was as much a tool of competition as one of cooperation and resulted from an interplay between cooperative and competitive logics. To explain the turn towards cooperative practices, the article looks at the complex constellation of competitive relations that existed within the national and international context of space exploration and changed in the late 1960s and early 1970s. The decisive role in those changes was played by factors that can be subsumed under the notion of the so-called "third."
\end{abstract}

Keywords Apollo Soyuz Test Project $\cdot$ Space Cooperation · Competition · The Third $\cdot$ NASA $\cdot$ Interkosmos

Darina Volf

Darina.Volf@1mu.de

1 Institute of Eastern and South Eastern European History, Ludwig Maximilian University of Munich, Geschwister-Scholl-Platz 1, 80539 Munich, Germany 


\section{Introduction}

For anyone who remembers the grim atmosphere of 1957-58, the Apollo

Soyuz mission must seem a political as well as scientific miracle.

— Beyond Soyuz-Apollo. The New York Times, 20 July 1975, p. E14.

On July 17, 1975, American astronaut Thomas Stafford and Soviet cosmonaut Aleksei Leonov exchanged their historic space handshake, an event that would have been hard to envisage only six years earlier. Back then, in July 1969, the space race culminated with the successful American lunar landing, and the global public was waiting for the Soviet response. The Space Business Daily expected the Soviet manned lunar mission to be attempted in October (Soviets may attempt 1969, p. 186). The rumors about an imminent spectacular Soviet spaceflight seemed to be confirmed in October 1969 with the launch of three Soyuz ships. However, after the mission, Western experts agreed that "Soviet officials, either by design or circumstance, did not create the 'space spectacular' widely forecast by many Russian and Western observers" (Gwertzman 1969: 14). Instead of a further escalation of the space race, what followed in the next years was a no less spectacular rapprochement between the two rivals that led to the first cooperative endeavor in manned spaceflight and, in the end, a docking between an American Apollo and a Soviet Soyuz spacecraft.

Although the accomplishment of this joint mission known as the Apollo Soyuz Test Project (ASTP) received huge media coverage and attention worldwide at the time, its history has not yet been examined in detail and from different perspectives. In particular, the Soviet perspective remains obfuscated because of the difficult access to Russian archival sources. In studies on the evolution of the ASTP, two explanations prevail: one stresses the professional motivation and engagement of space officials, and the other focuses on the political rationale behind space cooperation. Karash (1999) identifies "the convergence of purely professional interests" as the main factor leading to the ASTP. He argues that American and Soviet space officials started to consider cooperation as an adequate response to the challenges for their national space programs and pushed for it with little interference from politics (p. 90). On the other hand, Krasnyak (2018) and E. Sadeh, Lester and W. Sadeh (1996) emphasize the political symbolism of the project and view the ASTP as part of a wider political agenda that was enabled and defined by the détente in American-Soviet relations.

In this article, I attempt to reconsider the evolution of the ASTP from both a conceptual and an empirical perspective. Based on archival sources from Moscow, I shed some light on factors that led to a change in the previous reluctance of Soviet actors to cooperate with the United States in manned spaceflight. From the theoretical point of view, I use insights from Simmel's sociological writings to retell the history of the ASTP and offer a more complex picture of interests and motivations than so far suggested. I argue that the ASTP was as much a tool of competition as one of cooperation and the rationale behind its emergence was 
not a replacement of competition by cooperation but rather an interplay between cooperative and competitive logics.

The idea that cooperation and competition are not mutually exclusive but rather closely interrelated was already described for the history of science in general (Nickelsen and Krämer 2016) as well as for specific contexts, for example, the history of polar science (Launius, Fleming and Devorkin 2010; Soutschek and Nickelsen 2019). As for sensitive dual-use technologies such as nuclear power or space technology, John Krige pointed out the tension between transnational cooperation and circulation of knowledge, on the one hand, and rivalry and preeminence of national security interest, on the other, using the example of cooperation between the United States and Europe (Krige 2016, 2013). Looking at the symbolic dimension of space exploration, Anthony Shaw demonstrated how in the 1980s, the American and the Soviet space programs were competing at cooperation. Both superpowers tried to appear to the global public to be more cooperative than the rival was, and they portrayed their international space activities as a sign of the peaceful and cooperative nature of their space programs (Shaw 2013). In light of this research, it is rather surprising that similar considerations were not yet applied to the history of the American-Soviet space cooperation.

A greater emphasis on the interplay of cooperative and competitive logics in the ASTP enables a better understanding of "the miracle of cooperation" in the sensitive and fiercely contested field of space technology. To explain the turn towards cooperation, I look at the complex constellation of competitive relations that existed within the national and international context of space exploration. As I will argue, the various competitive situations began to change in the late 1960s and early 1970s and pushed the space programs of the United States and the Soviet Union towards a more cooperative mode of interaction. The decisive role in all those changes was played by factors that can be subsumed under the notion of the so-called "third."

\section{The Effects of the Third}

The German sociologist Georg Simmel was the first to draw particular attention to the significance and impact of a third element. Since then, the idea of the formative role played by a "third" has been incorporated into several concepts and disciplines (Cooper and Malkmus 2013). In cultural studies, adding a third category undermines dichotomous divisions and is central for concepts of hybridization such as Bhabha's (1994) notion of third space. A similar idea was applied to the history of the Cold War in order to problematize the dominant binary division and to draw attention to the in-between spaces, border areas, and those phenomena that elude the binary logic (Reichherzer et al. 2018). In this paper, the category of a third party is applied in order to describe how the space competition between the US and the Soviet Union changed in the late 1960s and early 1970s and pushed the rivals towards cooperation culminating in the ASTP.

The point of departure for my reflections on ASTP is Simmel's observation that adding a third party into a dyadic relationship has a transforming effect on interactions within this relationship. The third can perform various functions as mediator, 
arbitrator, or unbiased observer. Regardless of the specific function, the difference between dyadic and triadic relationships lies in the distraction of pure and immediate reciprocity between two actors and the addition of an intermediary who changes the nature and number of possible interactions (Wolff 1964: 135-136). In the following, I will focus on those aspects in the approaches to the "third" that touch on cooperative and competitive constellations.

The changes introduced to a dyadic relationship with the addition of a third party have far-reaching implications for prospects of cooperation, which is understood as the working together of two or more actors to achieve a goal that cannot, or only at very high cost, be achieved unilaterally. While in a dyad, cooperation is only possible between the two parties, a triangular constellation makes the situation instable and less predictable, since the triad may be dissolved into different formations of any two against the third. In this constellation, even a small party can gain considerable power when it becomes the decisive player who tips the scales.

The third enlarges options for cooperation, but he/she is even more important in a competitive constellation. The third party is constitutive and thus indispensable for competition as defined by Simmel (2008). The competition is understood as a struggle between two or more parties for the scarce favor of a third party. The third party ensures compliance with the rules, decides the struggle, and awards the prize. In fact, there is not just one competition with one prize; most actors are involved in different competitions, whereby one actor can be a competing party in one relationship and, at the same time, the third in another constellation. Furthermore, there are not only different competitions but also different prizes. To give an example connected to the ASTP, the American space program competed with other public programs for the prize of public funding awarded by the government. At the same time, the government competed with the opposition for power - a prize awarded by the electorate.

In addition, there was the widely publicized competition between the American and the Soviet space programs, which was part of the Cold War systemic rivalry. This competition may appear to be more difficult to grasp using Simmel's model since the third party and the prize are more abstract in this case. This applies not only to the space race but can be seen more generally as a specific feature of modern competitions that take place on a global scale. Describing these modern forms of competition, sociologist Tobias Werron (2014) introduced the notion of the imagined global audience that takes on the role of the third in those cases in which the competitors do not interact face-to-face but are instead dependent on modern media technology. With the help of intermediaries such as journalists, the global audience observes, compares, and evaluates the performances of competitors and thus fulfils the role of the third (p. 67). The prize awarded in this kind of competition is more difficult to quantify than money or electoral votes; it consists of "soft global goods" such as prestige, legitimacy, and attention (Werron 2012).

Based on these considerations, this article explains the cooperation within the ASTP as the result of the effects of the third in different but interrelated competitive contexts. First, it looks at the competition between the American and the Soviet space programs as a modern competition, in which the prize is prestige and the third party is the imagined global audience. Second, it shows that the window of opportunity for cooperation was opened as the result of the global audience's redefinition of 
space competition norms and expectations in the late 1960s and early 1970s. Third, the article focuses on the national space programs and demonstrates how the governments - in their role as the third in the competition for public funding - rearranged the competition and thus pushed the reorientation of the space programs towards cooperation. Finally, as is argued in the final part, the competitive environment changed in the late 1960s and early 1970s because of the appearance of new players who added complexity to the hitherto dyadic relationship.

\section{Space Firsts in the Cold War: Competition for Prestige}

The competition between the space programs of the United States and the Soviet Union fits into Werron's model of modern competition with mass media as intermediaries. Media drove and shaped Soviet and American competitive space efforts from the very beginning. Space historian Asif Siddiqi (2008) shows how print media in both countries became a crucial player in the decision to launch the first Soviet satellite in 1957. Also, in the further course of the space race, involved actors on both sides - space officials and politicians - closely followed media coverage. They were well aware that in the systemic rivalry of the Cold War, the space "firsts" were perceived publicly not only as a demonstration of technological capability but, in more general terms, as a sign of superiority of their respective political and economic systems. A (USIA 1959) report by USIA Office of Research Analysis dealing with the impact of Sputnik clearly demonstrates this effect:

The most significant and enduring result, for world public opinion of the launching of the first earth satellite by the USSR was a revolutionary revision of estimates of Soviet power and standing ... [,] a major revision in the image of the USSR and to some degree of the Soviet system.

Further, the report attempts to assess "world public opinion" and even tries to work out differences in perception of space achievements between individual world regions. Of course, what counts in the end and what the report actually deals with is less what people worldwide thought of the space programs than what the competing parties - in this case the Americans relying on media coverage - believed the people might think. This explains why Werron speaks of the global audience as imagined. It enables us to conceptualize the space race as a competition with the imagined audience as the third party and prestige as the prize to win. Not only the USIA report but also statements and actions by involved actors and observations in the literature (e.g. McDougall 1985: 317-319; Launius 2009: 92-93) imply the significance of prestige as the driving force behind the space programs. Courtland Perkins, who served as a member on the Space Sciences Board for National Aeronautics and Space Administration between 1965 and 1970, succinctly made the point by arguing that the Apollo program was an attempt "to restore [American] prestige in the eyes of the world" (1973: 1707).

The internal debates within the Soviet space program demonstrate that Soviet decisions were influenced by considerations related to the anticipated impact on prestige in the same manner as the American debates were. Soviet managers were ready to 
cancel planned missions in order to maintain the appearance of superiority. According to the diary of the head of Soviet cosmonaut training Nikolai Kamanin, a meeting on the future of the human spaceflight program Voskhod took place on May 10, 1966. The head of the Military-Industrial Commission, Leonid Smirnov, proposed to terminate the Voskhod 3 mission, which had already been postponed several times. One of his arguments emphasized the expected negative consequences of the mission for the Soviet Union's standing in the space competition: "[A] flight without maneuvers in orbit and without docking would display [the Soviets'] lag behind the U.S.A. and would be perceived by the public as proof of the superiority of the Americans" (Siddiqi 2000: 525; Kamanin 1966, entry from May 11). In 1969, shortly before the Apollo 11 mission, the Collegium of the Ministry of General Machine Building, ${ }^{1}$ which was already aware of the imminent defeat in the moon race, discussed the possibilities to save face and provide a somewhat adequate response to the American space spectacular (Stenogramma zasedanya kollegii 1969: 134).

The media as an intermediary between the audience and space managers fostered the competition between the American and the Soviet space programs by presenting them as rivals, using terms such as space race, formulating expectations concerning the right response to the challenge posed by the other side's achievements, and evaluating their performance. On the one hand, American and Soviet space managers adjusted their space programs to these expectations of the imagined global audience, as shown above. On the other hand, and hardly surprisingly, they did not remain passive observers of the audience's views but made a considerable effort to shape them actively by way of the public statements they issued. For example, NASA officials constantly attempted to relativize the Soviet supremacy in space by pointing out the technical sophistication and complexity of the American space program. When the Soviet cosmonaut Valentina Tereshkova became the first woman in space in 1963, NASA Deputy Administrator Hugh Dryden downplayed the significance of this achievement by claiming that Tereshkova had been in a kind of "chimp mode" (Griswold 2012: 894). The lunar landing of US astronauts led the Soviet side to deny its participation in the moon race and to emphasize the hazardous character of the American endeavor.

Nevertheless, space managers were well aware that they were not able to shape the public discourse freely without any consideration for public moods and sentiments. There were unwritten norms, expectations, as well as taboos. One example is the peaceful nature of space exploration, which both sides emphasized despite the fact that the potential use of space technologies for military applications accompanied the space programs from the very beginning. For this reason, the US side separated its military and civilian space programs, while the Soviet side shrouded its whole space program in secrecy (Siddiqi 2013: 55). The impact of the public sentiment on norms, rules, and evaluation criteria also explains why the American space program - despite surpassing the Soviets in the development of certain space technologies, such as docking systems in the mid-1960s ${ }^{2}-$ experienced difficulties

\footnotetext{
1 The Ministry of General Machine Building was responsible for the Soviet space program.

2 Already in the mid-1960s, Soviet space officials showed their awareness of the fact that the Soviet Union was not able to keep up with American docking technology (Siddiqi 2000: 525).
} 
in convincing the public of its superiority, or at least parity, as long as it still lacked a major space first. In a competition where the prize was prestige assigned by global audience and not by experts, space spectaculars were worth more than actual technological advancement or scientific benefits.

The lack of parity between the Soviet Union and the United States, which did not result from an actual technological gap but rather from public perception, had important consequences for the Soviet Union's willingness to cooperate with its rival. The US side made several attempts to approach the Soviets in the 1960s and proposed the pooling of Soviet and American efforts in the field of space exploration (Karash 1999: 27-30; Callahan 2013: 128-130). Nevertheless, such cooperation was only possible if both parties could agree to present to the outside world their joint efforts as equal partners. Neither of the Cold War rivals would have been willing to play the role of an inferior party. Consequently, as long as the Soviet lead in space remained uncontested in the public perception, the US side would benefit from a cooperation with the Soviets at eye level, as this would indicate the Soviet acknowledgement of parity. For the same reason, the coequal cooperation the Americans envisioned appeared unattractive for the Soviets. Only with the American lunar landing did the United States and the Soviet Union achieve a state of parity in public perception, which greatly increased the incentive of the Soviet Union to cooperate with the US side on equal terms. One might even argue that the lunar landing reversed the position of the rivals with regard to the interest in coequal cooperation. Now, the Soviets were more willing and in need to demonstrate parity by means of cooperation on an equal footing. Later, in the midst of preparations for the space handshake, this motivation was noticed by the Americans, who interpreted the Soviet insistence on the production of a film about ASTP as an attempt to showcase space parity (Memo from John P. Donnelly 1973).

However, in the late 1960s, American space managers found it hard to detect this Soviet motivation because further development on the Soviet side was unpredictable. Even though the United States won the moon race, which underpinned its claim to space leadership, the secrecy in which the Soviet space program was shrouded partly undermined this triumph. The reaction of the global public to the lunar landing mentioned above clearly demonstrates this difficulty. As long as the public was anticipating a sensational Soviet response, there was no final victory for the Americans. For US space officials trying to influence the public discourse, the secrecy and the lack of information on Soviet advances and plans posed a disadvantage for two main reasons. First, the US side found it difficult to react to Soviet plans for space missions, since they were not announced until Soviet space vehicles had been successfully launched into orbit. In contrast, the early announcement of American plans gave the Soviets the opportunity to take measures or at least to prepare public statements in advance. Second, the Soviet silence on their goals in space exploration made it possible to deny the existence of competition after the Soviet side had lost 
it. Accordingly, the Soviets claimed not to have lost the moon race, since they had never taken part in it.

For this reason, American space officials had great interest in finding out more about the status and future plans of the Soviet space program and could have benefitted from a more direct access gained in the course of cooperation. During a hearing before the Senate Committee on Aeronautical and Space Sciences in June 1972, NASA Deputy Administrator George Low presented the ASTP as the first step to figure out to what extent the Soviets were willing to relax their information policy. At the same time, he made further cooperation dependent on more information about Soviet plans for future space exploration (Hearing before the Senate Committee 1972, 10). This also explains why the American participants of the ASTP, especially the ASTP director Glynn Lunney, regularly put pressure on their Soviet counterparts to disclose more information on various aspects of the Soviet space program, for example, on the failure of Soyuz 11 (Letter from Lunney to Bushuyev, 1973, n.p.), on flight data of Salyut (Transcript of the phone call between Lunney and Bushuyev, 1974, p. 128) or on future plans in the Soviet space program (Letter from Lunney to Bushuyev, 1975, n.p.).

On the other hand, a report by Mstislav Keldysh, President of the USSR Academy of Sciences and one of the key figures of the Soviet space program, provides evidence of the Soviet side being aware of this motivation behind the US interest in cooperation. Keldysh, who reported to the Presidium of the Academy of Sciences after his visit in the United States in December 1972, said that Americans were afraid of new Soviet surprises in space, as somebody told him explicitly during a meeting (Stenogramma Zasedanya Prezidiuma Akademii nauk 1972).

\section{Shrinking Interest in the Space Race and Changing Expectations of the Global Audience Since the Late 1960s}

Although the space officials were still thinking in terms of competitiveness and rivalry in the early 1970s, the changes on the side of the third - the global public - posed a major threat for space competition. The end of the race to the moon led to a considerable decrease in public attention for the space race (Geppert 2018: 12), accompanied by the more general decline in the belief of the centrality of science and technology (McDougall 1985: 444; Wolfe 2013: 104-105). A report by the Space Task Group (1969) that President Richard Nixon established in February 1969 to formulate recommendations for the post-Apollo space program pointed out the changing attitude of the American public: "Today, new Soviet achievements are not likely to have the effect of those in the past." A "shock" similar to that expressed by the American public with the launch of Sputnik was hardly conceivable at the end of the 1960s.

For this and other reasons that I will discuss further below, Nixon turned away from the space race and put an emphasis on cooperation. The idea of space cooperation was not new. Already in the 1960s, NASA concluded cooperative arrangements with several Western allies, after they were invited to participate in the NASA's program at the March 1959 COSPAR meeting (Krige 2007: 208-209). Apart from that, 
there were also discussions on possible joint endeavors with the Soviet rival already during the Kennedy administration. However, these efforts did not materialize, so that all activities concentrated on the race to the moon. The struggle to surpass the Soviets also seemed to be the more appropriate response, after the Sputnik launch and the Cuban missile crisis had triggered public fears regarding national security.

In contrast, the atmosphere of détente during the Nixon administration increased the prospects for the global public's receptivity to the idea of space cooperation. First, easing of tensions between East and West, breakthroughs in the sensitive topic of arms control and the intensifying inter-bloc contacts in different fields proved that cooperation across the "iron curtain" was possible. Second, the raising awareness of Earth's vulnerability fostered by photos of Earth from space such as "Earthrise" or "Blue Marble" taken by Apollo astronauts (see Geppert 2018: 9) demonstrated that international cooperation on global problems was also necessary. Thus, paradoxically, the unintended consequence of the space race was the growing felt need for space cooperation.

The public's receptivity for the idea of cooperation is reflected in the press coverage at that time. Already a cursory look at the frequency of the simultaneous occurrence of the words "space" and "cooperation" in the coverage of the New York Times and Washington Post but also the German Frankfurter Allgemeine Zeitung indicates an increase in $1969 .{ }^{3}$ Thus, the space managers on both sides had good reason to assume that cooperation rather than competition was becoming the dominant expectation of the global audience.

Because of the rising importance of cooperativeness, it was reasonable to present one's own space program as more cooperative than the rival's program. From the beginning, the portrayal of American space efforts focused on openness and the sharing of data with the international scientific community (Rockwell 2013: 133). However, after the lunar landing, NASA officials not only accentuated cooperation in general but also highlighted American initiatives to approach the Soviet rival. At the same time, they blamed the lack of cooperation between the space powers on the Soviets. Several articles described many attempts by NASA to induce cooperation and its disappointment over the Soviets' "tepid response." For example, in March 1970, NASA Administrator Thomas Paine mentioned to Richard Lyons of the New York Times that NASA had tried to initiate discussions on cooperation with the Soviets 27 times in the past decade. According to Paine, the Soviets either rejected these offers or ignored the NASA's letters completely.

Needless to say, the Soviet Union also had a major interest in appearing cooperative to the global public. Already in 1960, the Academy of Sciences warned the Central Committee of the party that the refusal to participate in the planned International Academy of Astronautics could be interpreted as a sign of Soviet

\footnotetext{
3 The search for the phrases "cooperation in space" or "space cooperation" in the New York Times results in 10 hits for 1967, 7 for 1968, and 19 for 1969; in the Washington Post, there are 5 hits for 1967, 2 for 1968, but 13 for 1969. In the Frankfurter Allgemeine Zeitung, there is only one reference in 1968 (regarding European cooperation), but three references in 1969, all of them referring to cooperation in the global context.
} 
non-cooperativeness in international space activities (Ob uchrezhdenii Mezhdunarodnoi Akademii astronavtiki 1960). However, arguments against participation prevailed at that time, and the Soviet Union initially did not join the Academy.

In the late 1960s, the situation changed, since the idea of space cooperation found more resonance in the public. Thus, the media coverage on Soviet unresponsiveness to NASA's initiatives was more damaging to the Soviet prestige. Archival evidence suggests that Soviet space managers paid it great attention. A report from 1971 lists a set of documents on the state of American-Soviet cooperation (Sovetsko-amerikanskoe sotrudnichestvo 1971). It also includes press articles dealing with the Soviet reluctance towards cooperation. For example, an article by Paul Scott published in the New York Daily News in July 1969, blames the Soviet Union for obstructing international space cooperation by sending to NASA useless data and ignoring all cooperative proposals. In February and March 1970, the Academy of Sciences translated two articles into Russian, one from a French journal and the above-mentioned article by Richard Lyons. ${ }^{4}$ Interestingly, the decision to start talks on space cooperation with NASA was made just a few weeks later, on May 13, 1970 (Spravka 1972). The intensifying media coverage on the negative attitude of the Soviets towards American cooperation initiatives was a serious disadvantage in the competition over a country's national image at a time when the imagined global audience favored cooperation over competition. The careful monitoring of such articles by the Soviet side indicates that the unfavorable coverage put pressure on Soviet space officials to prove to the public their proclaimed interest in cooperation.

Taken together, the lunar landing changed the competition between the American and the Soviet space programs in several ways, all of which pushed the competing parties in the direction of cooperation. The American gain in prestige inverted the relational position of the two rivals and increased the incentive of the Soviet side to cooperate on an equal footing. At the same time, as the global audience's aversion to a race in space exploration was rising, the competing parties had to adjust their actions to conform to the altered expectations. Finally, the shrinking interest of the imagined global audience in this kind of competition in general required a new strategy from the competitors in order not to lose the public's attention completely - a realistic threat, which I discuss in the next part.

\section{Reshuffling National Priorities: A Crisis of the Space Programs on Both Sides of the Iron Curtain}

The dwindling public interest in space exploration posed a challenge not only to the competition between the two rivals on a global scale but also to the competition between the space program and other domestic public sectors on the level of domestic politics. Because of the high costs of space exploration, the space programs were

\footnotetext{
4 The second article was published in Air \& Cosmos on February 7, 1970. Both translated articles are in fond 1678 (Interkosmos), opis' 1, delo 93, Archive of Russian Academy of Sciences (henceforth ARAN), Russia, Moscow.
} 
dependent on state funding. The allocation of scarce state resources was the prize aspired to by many different sectors of society and awarded by the government. However, while the government served as the third party in this competition for state funding, in a democratic system it also took on the role of a competing party in the competition for the favor of the electorate. These competitions were closely interrelated. The allocation of public funds by the government had an impact on the electoral choice, and the preferences of the electorate, in turn, affected priorities and thus budget decisions of the government. Consequently, the amount of public funding for the space program depended on how much relevance and priority society assigned to the task of space exploration.

At the same time, a powerful presidency was able to mobilize support for expensive space endeavors, ensure a broad political consensus, and positively affect public opinion on space flight, as the example of the decision to go to the moon shows (Beschloss 1997). This also meant that space managers in the United States were required to meet the expectations and compete for the favor of both the government and the public. Yet at the same time, they could exert some influence in the political competition, at least as long as space exploration enjoyed great public attention. On the one hand, the accomplishments in space could provide the government with electoral benefits. On the other hand, every failure in the space program offered a welcome target for criticism, as the example of President Eisenhower's vulnerability after Sputnik demonstrated (Mieczkowski 2013: 23-24).

Because of the nature of the Soviet political system with one ruling party instead of democratic party competition for the electorate's favor, the Soviet space program was not as vulnerable to public opinion as the American was. Nevertheless, it would not be appropriate to take for granted the often-repeated assumption that Soviet elites were completely unconcerned with public sentiments. Of course, the censored official media was not allowed to openly criticize the Communist Party, so at first sight it might seem that the allocation of state resources was shielded from media scrutiny and free from public pressure. However, the fact that the political communication between the ruling class and society was not carried out in the media does not mean that the party paid no attention to society's concerns and expectations. Quite the contrary is true, as studies challenging the totalitarian interpretations of communist systems point out. Even in the most repressive periods of Soviet history, the elites monitored public sentiments, complaints, and rumors very closely, for instance through reports from the secret police (Davies 1997; Fitzpatrick 1996). Since concession and accommodation were more efficient than coercion, the party leadership reacted to various articulations of public discontentment either through policy measures or at least with public statements in the media. So, even if the position of the Soviet public in the triad connecting it with the space program and political elites was weaker than in the United States, public opinion cannot be ignored completely when it comes to the competition between different public sectors for the ruling elites' favor in the form of state funding.

In the United States, the relative position of the space program in the domestic competition began to change already in the second half of the 1960s. After several years of constant growth in the NASA's share of the federal budget, the first cuts in funding occurred in 1967. NASA's budget started to shrink in both absolute 
and relative terms. The lunar landing accelerated this process and led to further decreases in funding and the loss of human resources, because many employees left NASA or companies contracted by NASA. In addition, there was widespread uncertainty about the future orientation of the space program. Since an American space first had become a priority goal in the 1960s and all the efforts had been directed towards achieving it, NASA had turned into a "single-issue agency," (Launius 1994: 93) and little thought was given to the fate of the space program after the accomplishment of this goal.

This crisis in the US space program, though particularly striking after the lunar landing, was not the result of a paralyzing complacency after the great success but was caused instead by shifting societal and political priorities. Despite the fact that the space program and spending on space exploration did not enjoy such a high degree of public support at the onset of Apollo as many believe (Launius 2003: 167-168), it was still sufficient to define the lunar landing as one of the country's national priorities. But a few years later, the voices of those who called for solving problems on Earth, such as poverty and disease, instead of undertaking expensive space adventures became louder, and the number in favor of cutting space spending was rising (Roy et al. 2000: 670). Nixon, who was "a careful reader of opinion polls and other indications of public sentiment," took measures to avoid the impression that he supported space flight at the expense of social programs (Logsdon 2015: 278). Of particular importance was his decision to downgrade the space program from a national security and foreign policy issue to a domestic issue, and thus from a top priority to merely one issue among others (Logsdon 2015: 108).

A similar reshuffling of national priorities was taking place behind the scenes in the Soviet Union. Of course, there were no openly critical statements in the media or public opinion polls on support for space endeavors. However, some attempts of space program supporters to defend it against criticism indicate that there was awareness for the necessity to justify space spending to the public. For example, in May 1969, an article in the daily newspaper Izvestia asked why space exploration was necessary and what humanity was going to get in exchange. According to the author Oleg Chembrovsky, the chairman of the All-Union Committee on Cosmonautics of the DOSAAF (All-Union Voluntary Society for Cooperation with the Army, Navy and Air Force), such questions were asked often and not only by enthusiastic supporters of the space programs but also by sceptics.

In June 1970, Izvestia correspondent Boris Konovalov criticized those people who grumbled that there was no need for a space program, even though they watched television "somewhere in the Extreme North or the Far East" and relied on the weather forecast obtained with the help of meteorological satellites. Academician Leonid Sedov ${ }^{5}$ defended the space program by pointing out the practical applications of technological and scientific progress for daily life. Moreover, he used the

\footnotetext{
${ }^{5}$ Leonid Sedov, chairman of the Permanent Interdepartmental Commission on Interplanetary Communications of the Academy, was falsely believed to be the "father of Sputnik" in the late 1950s, since he represented the Soviet space program to the outside world. The real figures behind it were kept secret (Siddiqi 2013: 66-67).
} 
"falling behind" rhetoric in order to emphasize the imperative of a vigorous space program (Gwertzman 1971: 14; Siddiqi 2011: 295). Such statements did not go unnoticed in the United States, where the media concluded: "From speeches made by Soviet leaders . . . it seems that proponents of the Soviet space program have been pressed in the same way as their American counterparts to justify the costly appropriations that a dozen years ago were given almost without question" (Gwertzman 1971: 14).

Despite all efforts of Soviet space officials to legitimize and popularize the space program, political elites were no longer willing to provide it with the same level of support and commitment as in the years shortly after the Sputnik launch. A CIA (1969) report, which aimed at estimating capabilities and possible achievements of the Soviet space program, mentioned the declining growth of Soviet space expenditures since 1965. According to the report, this decline was due to the general decline of economic growth, which led to an intensified competition for resources between different domestic fields.

For the Soviet space officials, it was unfavorable that the competition for resources intensified at the same time that the relative position of the space program within this competition deteriorated for various reasons. First, there was a change in the ruling elite in 1964. Siddiqi (2000) argues that the space program lost its relatively uncontrolled access to funding once Leonid Brezhnev assumed power because he was less supportive of it than his predecessor Nikita Khrushchev was (p. 552). Second, the space program lost its most important driving force when Sergey Korolev died in 1966. Vasily Mishin, who succeeded Korolev as the chief designer, was perceived as weak and hesitant with poor managerial and leadership skills (Harvey 2007: 87-88; Kamanin 1966, entry from August 5). Finally, the Soviet public's cosmic enthusiasm waned after a series of disasters and losses. Apart from the sudden passing of Korolev, there was the fatal accident of Vladimir Komarov during the Soyuz-1 mission in 1967 and the death of Yuri Gagarin in a plane crash in 1968 (Siddiqi 2011: 294). So, since the mid-1960s, the weakened Soviet space program faced intensifying funding competition and struggled with the decreasing interest of its decisive arbitrators, namely, political elites and the public.

Despite different political systems, the US and Soviet space programs faced similar challenges starting in the mid-1960s, which resulted from a restructuring of national priorities and led to the deteriorating competitiveness of the space programs relative to other state-funded areas and programs. Consequently, both space programs had to react to the new situation. The two obvious options were either to adapt to the limited budget by reducing costs or to try to increase the visibility of the space program and thus its public and political support. A cooperative approach to space endeavors seemed to be a feasible way to achieve both - to share the costs and risks of space exploration and to enhance the visibility of the space program and boost public enthusiasm and interest (Geppert 2018: 16). Of course, the pressure on the US space program was greater and more direct, forcing the American space managers to respond more urgently. Space cooperation became a publicly promoted goal for NASA as well as for President Nixon. In view of the failure of previous American initiatives for cooperation with the Soviets, the United States felt that it had to look for other partners, especially in Western Europe (Krige 2013: 68; 
Geppert 2018: 16). However, for different reasons, the negotiations with Europeans proceeded rather slowly (Sebesta 1994: 329-334). What is more, this American initiative came at a moment when the appearance of new actors destabilized the hitherto dyadic constellation of the space competition, and this posed a threat to the Soviet space program, so that the Soviets were pushed to rethink their stance on cooperation.

\section{New Players Destabilizing the Dyadic Constellation}

Broadening international cooperation as a means "to share benefit and cost of space exploration" was proposed in the report "The Post-Apollo Space Program: Directions for the Future" written by the Space Task Group in September 1969. Based on recommendations outlined in the report, President Nixon called for "internationalizing man's epic venture into space" in his address to the United Nations on September 18,1969 . The speech rejected the principle of rivalry and emphasized the "spirit of fraternal cooperation that so long has been the hallmark of the international community of science." As it soon turned out, this commitment to international space cooperation before the eyes of the international community was more than mere lip service to demonstrate American cooperativeness. A few months later, in March 1970, Nixon indicated concrete steps the NASA Administration had taken to foster space cooperation, and he mentioned meetings with authorities of Western Europe, Japan, Canada, and Australia (Nixon 1980).

For the further course of this advance towards international cooperation, it was essential that the prospects for cooperative efforts in space changed fundamentally in the second half of the 1960s. In the early 1960s, the enormous technological gap between the United States and the European Launcher Development Organization (ELDO), founded only in 1962, "limited the areas of technological collaboration that could be of mutual interest" (Krige 2013: 57, see also Sebesta 1994: 321). The same applies to Indian space activities, so that the connection to the US space program was possible more in terms of unidirectional assistance rather than cooperation. As for Japan, apart from the lack of coordinated space activities, another factor hindering American-Japanese space cooperation were personal animosities (Maharaj 2013: 188). Hence, during the Kennedy Administration, proposals for cooperation in most technologically ambitious space activities such as manned space exploration were aimed primarily at the Soviet Union, and the overall constellation can be described as more or less dyadic.

In contrast, in the late 1960s, the number of countries systematically involved in space exploration was growing and so was the scope of their commitment. European countries intensified their space efforts in order to become less dependent on American technology. In 1968, China started its efforts to send humans into space. The Indian Space Research Organization (ISRO), founded in 1969, set itself the goal of developing indigenous competence in space technology (Maharaj 2013: 222). These developments caused the above-mentioned effect of a third player who transforms a dyad into a completely different structure. Here, the actual number of the players is not important because, as Simmel argues, a triad is "a structure completely different 
from the dyad but not, on the other hand specifically distinguished from groups of four or more members" (Wolff 1964: 141). The key point is rather that the formerly dyadic relationship with two rivals was replaced by a complex constellation with different possibilities for cooperative alliances. This constellation bore the risk of becoming an outsider in case of a reluctant stance towards any form of cooperation.

For this reason, the US initiatives to approach the emerging space-faring nations must have been alarming for Soviet space managers. Like their American counterparts, they recognized the significance of international space cooperation and tried to make it broader and more effective. For this reason, in 1966, the Council on International Cooperation in Research and Uses of Outer Space, known as Interkosmos, was established at the Academy of Sciences. However, the attempt to extend international space cooperation encountered many obstacles in the Soviet Union. Partly, it was due to the above-mentioned secrecy. Nevertheless, many problems arose from internal bureaucratic procedures, as was discussed at a meeting of the Interkosmos in April 1972. General Director of the Interkosmos program Viacheslav Kovtunenko complained about the lack of attention to the implementation of Soviet international commitments on the side of the ministries. According to Kovtunenko, the indifference caused major delays and problems, for example in the case of Indian-Soviet cooperation (Protokol zasedaniya 1972). Similarly, a report from the early 1970s on the perspectives of space cooperation identified secrecy and bureaucratic hurdles as the main problems for the participation of the Soviet Union in international space programs (Otchet po teme 'DAL'-4', p. 144-146).

Given the difficulties with international space cooperation, Soviet officials had every reason to fear their exclusion from international efforts should they maintain the status quo. The above-mentioned report with the documents related to American-Soviet cooperation also mentions the invitation of NASA to "all countries to scientifically participate in the Viking program" (Sovetsko-amerikanskoe sotrudnichestvo 1971). The imminent threat of "remaining outside" pushed the Soviet Union towards a demonstration of its presence in the international space community. The report "Opredelenie osnovnyh napravlenij" (Opredelenie osnovnyh napravlenij 1975) reflecting in retrospect on advantages and disadvantages of the ASTP demonstrates the importance of this "imperative of presence" for the Soviets. One of the major advantages mentioned in the report in the first place was an increase in the Soviet Union's prestige "as a leading nation in science and technology, without which major international space projects would be impossible."

Because of the lack of transparency regarding Soviet decisions on the country's space program, the American side could hardly foresee the transforming nature of the above-mentioned developments on the willingness of the Soviet Union to cooperate. The CIA report on the Soviet space program from 1969 was skeptical about the prospects for cooperation with the Soviets. Although it admitted that some limited cooperation might be possible, it considered it unlikely "that within the period of [the] estimate, the Soviets will be willing to cooperate to the extent of exchanging space hardware." In October 1969, notwithstanding the weak prospects, NASA Administrator Paine sent the reports "The Post-Apollo Space Program" and "NASA's Report to the Space Task Group" to the President of the Academy of Sciences Keldysh and proposed to move beyond the hitherto very limited 
American-Soviet cooperation. Surprisingly, the response by Keldysh offered more reason for optimism than ever before. In his letter dated December 12, 1969, Keldysh admitted that mutual cooperation was still very limited. Although he did not promise any concrete steps to change this, he neither refused nor ignored the American proposal. Instead, he asked for more time with the justification that such a cooperation needs good preparation (Letter from Mstislav Keldysh 1969). Keldysh needed this time to mobilize enough support within the political elite. In April 1970, he and the Minister of General Machine Building Sergey Afanasyev recommended negotiations with NASA and sent a memo to the chairman of the Military-Industrial Commission Smirnov (Spravka 1972). Finally, in May 1970, the Central Committee of the Communist Party decided to start talks with NASA and cleared the way for negotiations on the first American-Soviet joint mission and the first space handshake.

\section{Conclusion}

The cooperative efforts during the preparations for the ASTP mission did not reflect a replacement of competitive with cooperative logic. Rather, the ASTP is a good example of an interplay between cooperation and competition. The actors involved in the decision making for the space program in both countries acknowledged that, in light of the changes that occurred in the late 1960s, it was reasonable to turn to the cooperative mode in order to maintain the competitiveness of the space program. On the global scale, the space competition for prestige was modified by a shift in the norms and expectations of the global audience in its role as the third party. The race for space firsts inevitably created a zero-sum game and left no room for cooperation. In contrast, the growing importance of down-to-earth considerations but also the occurrence of new players privileged cooperation. In order for the competitors to be awarded with prestige by the global audience, they had to demonstrate their cooperativeness. Thus, they started to compete at cooperation.

The efficiency and cooperativeness of the space program was not just an advantage for the global competition but also an imperative resulting from the domestic competition with other public sectors and programs. At this point, it becomes clear how closely interwoven the competitive constellations were. The shrinking significance of the space race in general forced the political elites to change the list of national priorities, and this led to a repositioning of the space program within the competition for state funds. Consequently, the space managers also had to adapt their strategy in order to maintain the competitiveness of their respective space programs on both the domestic and global scales despite the budget cuts. Here, the space programs of the United States and the Soviet Union were not only in a similar situation but positively interdependent on each other, since the cuts in funding on the one side would challenge high level of space expenditures on the other side. Under the motto "either we swim or sink together," it was reasonable for both space programs, compared with other domestic sectors, to strengthen their competitiveness by cooperating and keeping the other in the game. 
Funding Open Access funding enabled and organized by Projekt DEAL. This work was supported by the German Research Foundation.

\section{Compliance with Ethical Standards}

Conflict of interest The author declares that she has no conflicts of interest.

Open Access This article is licensed under a Creative Commons Attribution 4.0 International License, which permits use, sharing, adaptation, distribution and reproduction in any medium or format, as long as you give appropriate credit to the original author(s) and the source, provide a link to the Creative Commons licence, and indicate if changes were made. The images or other third party material in this article are included in the article's Creative Commons licence, unless indicated otherwise in a credit line to the material. If material is not included in the article's Creative Commons licence and your intended use is not permitted by statutory regulation or exceeds the permitted use, you will need to obtain permission directly from the copyright holder. To view a copy of this licence, visit http://creativecommons.org/licen ses/by/4.0/.

\section{References}

Beschloss, Michael R. 1997. Kennedy and the decision to go to the moon. In Spaceflight and the myth of presidential leadership, eds. Roger D. Launius and Howard McCurdy, 51-67. Urbana: Univ. of Illinois Press.

Beyond Soyuz-Apollo. 1975. The New York Times, 20 July, E14.

Bhabha, Homi K. 1994. Location of Culture. London: Routledge.

Callahan, Angelina Long. 2013. NASA and the Soviet Union/Russia. In NASA in the world: Fifty years of international collaboration in space, eds. John Krige, Angelina Long Callahan and Ashok Maharaj, 127-184. New York: Palgrave Macmillan.

Chembrovsky, Oleg. 1969. Zemlja - Kosmos - Zemlja [Earth - Space - Earth]. Izvestia, 22 May, 3.

CIA. 1969. The Soviet Space Program, National Intelligence Estimate 11-1-69, 19 June 1969. The National Security Archive. https://nsarchive2.gwu.edu/NSAEBB/NSAEBB501/docs/EBB-16a. pdf. Accessed 2 December 2020.

Cooper, Ian, and Bernhard Malkmus. 2013. Triadic concepts in the humanities and social sciences: An introduction. In Dialectic and paradox: Configurations of the third in modernity, eds. Ian Cooper and Bernhard Malkmus, 1-21. Oxford: Lang.

Davies, Sarah. 1997. Popular opinion in Stalin's Russia: Terror, propaganda and dissent 1934-1941. Cambridge: Cambridge University Press.

Fitzpatrick, Sheila. 1996. Supplicants and citizens: Public letter-writing in Soviet Russia in the 1930s. Slavic Review 55: 78-105.

Geppert, Alexander C.T. 2018. The Post-Apollo paradox: Envisioning limits during the planetized 1970s. In Limiting outer space: Astroculture after Apollo, ed. Alexander C.T. Geppert, 3-26. New York: Palgrave Macmillan.

Griswold, Robert L. 2012. 'Russian blonde in space': Soviet women in the American imagination, 1950-1965. Journal of Social History 45: 881-907.

Gwertzman, Bernard. 1969. Soyuz 7 lands in Soviet; 3d craft is expected today. The New York Times, 18 October, 14.

Gwertzman, Bernard. 1971. High space costs backed in Soviet: Expert says big outlays for research are justified. The New York Times, 28 February, 20.

Harvey, Brian. 2007. Soviet and Russian lunar exploration. Berlin: Springer.

Hearing before the Senate Committee on Aeronautical and Space Sciences on June 23, 1972, material requested for the record on pages 54-5 by Senator Weicker. 1972. RG 255, 77A0090, box 2. Apollo Soyuz Test Project Files, 1971 - 1975, MSFC. National Archives at Atlanta, USA.

Kamanin, Nikolai P. 1995. Skrytiy kosmos: kniga vtoraya, 1964-1967 gg. [Hidden cosmos: second book, 1964-1967]. Moscow: Militera. http://militera.lib.ru/db/kamanin_np/66.html. Accessed 2 December 2020. 
Karash, Yuri. 1999. The superpower odyssey: A Russian perspective on space cooperation. Reston: American Institute of Aeronautics and Astronautics.

Konovalov, Boris. 1970. Iz pokoleniya tridcatiletnih [From the generation of the thirty-years-old people]. Izvestia, 2 June, 3.

Krasnyak, Olga. 2018. The Apollo-Soyuz Test Project: Construction of an ideal type of science diplomacy. The Hague Journal of Diplomacy 13: 410-431.

Krige, John. 2007. NASA as an instrument of U.S. foreign policy. In Societal Impact of Spacefight, eds. Steven J. Dick and Roger D. Launius, 207-218. Washington D.C.: NASA.

Krige, John, Angelina Long Callahan, and Ashok Maharaj (eds.). 2013. NASA in the world: Fifty years of international collaboration in space. New York: Palgrave Macmillan.

Krige, John. 2013. Technology transfer with Western Europe: NASA-ELDO relations in the 1960s. In NASA in the world: Fifty years of international collaboration in space, eds. John Krige, Angelina Long Callahan and Ashok Maharaj, 51-64. New York: Palgrave Macmillan.

Krige, John. 2016. Sharing knowledge, shaping Europe: US technological collaboration and nonproliferation. Cambridge: The MIT Press.

Launius, Roger D. 1994. NASA: A history of the U.S. civil space program. Malabar: Krieger.

Launius, Roger D. 2003. Public opinion polls and perceptions of US human spaceflight. Space Policy 19: $163-175$.

Launius, Roger D. 2009. United States space cooperation and competition: Historical reflections. Astropolitics 7: 89-100.

Launius, Roger D., James Rodger Fleming, and David H. Devorkin. 2010. Globalizing Polar Science: Reconsidering the International Polar and Geophysical Years. New York: Palgrave Macmillan.

Letter from Glynn Lunney to Konstantin Bushuyev. 1975. 7 January. RG 255-E267, box 4, ASTP Transmittals. National Archives at Fort Worth, USA.

Letter from Glynn Lunney to Konstantin Bushuyev. 1973. 24 August. RG 255-E267, box 2, ASTP Transmittals. National Archives at Forth Worth, USA.

Letter from Mstislav Keldysh to Thomas Paine. 1969. 12 December. Fond 1678 (Interkosmos), opis' 1, delo 93, ARAN.

Logsdon, John M. 2015. After Apollo? Richard Nixon and the American space program. New York: Palgrave Macmillan.

Lyons, Richard D. 1970. NASA seeks links to Soviet science but Moscow response to 7 letters has been tepid. The New York Times, 12 March, 9.

Maharaj Ashok. 2013. An overview of NASA-India relations. In NASA in the world: Fifty years of international collaboration in space, eds. John Krige, Angelina Long Callahan, and Ashok Maharaj, 211-234. New York: Palgrave Macmillan.

Maharaj, Ashok. 2013. An overview of NASA-Japan relations from pencil rockets to the International Space Station. In NASA in the world: Fifty years of international collaboration in space, eds. John Krige, Angelina Long Callahan, and Ashok Maharaj, 185-196. New York: Palgrave Macmillan.

McDougall, Walter. 1985. The Heavens and the Earth: A Political History of the Space Age. New York: Basic Books.

Memo from John P. Donnelly, Assistant Administrator for Public Affairs to Program Director ASTP. 1973. 20 September. RG 255-264, box 7, Test Project Documents, 1972-1975, National Archives at Fort Worth, Texas, USA.

Mieczkowski, Yanek. 2013. Eisenhower's Sputnik moment: The race for space and world prestige. Ithaca, NY: Cornell University Press.

Nickelsen, Kärin, and Fabian Krämer. 2016. Introduction: Cooperation and competition in the sciences. NTM 24: 119-123.

Nixon, Richard. 1969. Address by President Richard Nixon to the UN General Assembly. U.S. Department of State, 18 September. https://2009-2017.state.gov/p/io/potusunga/207305.htm. Accessed 4 May 2020.

Nixon, Richard. 1980. Statement by President Nixon on the Space Program, 7 March 1970. In Beyond the atmosphere: Early years of space science, ed. Homer E. Newell, 441-443. Washington, DC: National Aeronautics and Space Administration.

Ob uchrezhdenii Mezhdunarodnoi akademii astronavtiki v ramkach mezhdunarodnoi astronavticheskoi federatsii [About the foundation of the International Academy of Astronautics in the framework of the International Astronautical Federation]. 1960. 13 May. Fond 5, opis' 35, delo 133, 11. 66-68, Russian State Archive of Contemporary History (RGANI), Russia, Moscow. 
Opredelenie osnovnyh napravlenij razvitija kosmicheskih issledovanij po nauchnym programmam mezhdunarodnogo sotrudnichestva - otchet po nauchno-issledovatel'skoj teme [The definition of main directions for the development of space research in the field of international cooperation programs - report on research topic]. 1975. Fond 1862 (Institut kosmicheskih issledovanij [Institute for Space Research, henceforth IKI]), opis' 2, delo 41, ARAN.

Otchet po teme 'DAL'-4': Kniga 1: Opredelenie perspektiv razvitiia kosmicheskikh issledovanii po nauchnym programmam mezhdunarodnogo sotrudnichestva [Report on the topic DAL'-4: Book 1: The definition of perspectives for the development of space exploration in international space programs]. 1974. 15 July. Fond 1862 (IKI), opis' 2, delo 10, ARAN.

Perkins, Courtland D. 1973. A look at our national space program. Hon. Courtland Perkins, Dean of Engineering, Princeton University, addresses luncheon meeting of the American Institute of Aeronautics and Astronautics on 20 January. In Record of the House of Representatives of the US Congress. Extensions of Remarks, vol. 119, part 2, 1707.

Protokol zasedaniya Soveta "Interkosmos" pri AN SSSR [Minutes of a meeting of the Council Interkosmos of the Academy of Sciences of the USSR]. 1972. 26 April. Fond 1678 (Interkosmos), opis' 1, delo 218, ARAN.

Reichherzer, Frank, Emmanuel Droit, and Jan Hansen (eds.). 2018. Den Kalten Krieg vermessen. Über Reichweite und Alternativen einer binären Ordnungsvorstellung [Measuring the Cold War: on the boundaries, scope, and alternatives to a binary notion of order]. Berlin: De Gruyter.

Rockwell, Trevor S. 2013. They may remake our image of mankind: Representations of cosmonauts and astronauts in Soviet and American propaganda magazines, 1961-1981. In Spacefarers: Images of astronauts and cosmonauts in the heroic era of spaceflight, ed. Michael J. Neufeld, 125-147. Washington, DC: Smithsonian Institution Scholarly Press.

Roy, Stephanie A., Elaine C. Gresham, and Carissa Bryce Christensen. 2000. The complex fabric of public opinion on space. Acta Astronautica 47: 665-675.

Sadeh, Eligar, James P. Lester, and Willy Z. Sadeh. 1996. Modeling international cooperation for space exploration. Space Policy 12: 207-223.

Sebesta, Lorenza. 1994. The politics of technological cooperation in space: US-European negotiations on the Post-Apollo programme. History and Technology 11: 317-341.

Shaw, Anthony J. 2013. Competing at cooperation: Technological design and propaganda representations of Soviet and American space programs, 1981-1986. Quest 20: 41-49.

Siddiqi, Asif A. 2000. Challenge to Apollo: The Soviet Union and the space race, 1945-1974. Washington, DC: National Aeronautics and Space Administration.

Siddiqi, Asif A. 2008. Sputnik 50 years later: New evidence on its origins. Acta Astronautica 63: 529-539.

Siddiqi, Asif A. 2011. From cosmic enthusiasm to nostalgia for the future: A tale of Soviet space culture. In Soviet space culture: Cosmic enthusiasm in socialist societies, eds. Eva Maurer, Julia Richers, Monica Rüthers, and Carmen Scheide, 283-306. London: Palgrave Macmillan.

Siddiqi, Asif A. 2013. Cosmic contradictions: Popular enthusiasm and secrecy in the Soviet space program. In Into the Cosmos: Space Exploration and Soviet Culture, eds. James T. Andrews and Asif A. Siddiqi, 47-76. Pittsburgh: University of Pittsburgh Press.

Simmel, Georg. 2008. Sociology of competition. The Canadian Journal of Sociology 33: 957-978.

Soutschek, Liza, and Kärin Nickelsen. 2019. „Zusammenwirken“ oder „Wettstreit der Nationen“: Kooperation und Konkurrenz in der deutschen Antarktisexploration um 1900. NTM 27: 229-263.

Sovetsko-amerikanskoe sotrudnichestvo v razlichnych oblastjah issledovaniya kosmicheskogo prostranstva - spravka [Soviet-American cooperation in various fields of space research - information]. 1971. Fond 1678 (Interkosmos), opis' 1, delo 110, ARAN.

Soviets may attempt manned lunar flight by Oct. 29. 1969. Space Business Daily, 13 October, 186-187.

Space Task Group. 1969. The Post-Apollo Space Program: Directions for the Future. Available in NASA Historical Reference Collection, History Office, NASA Headquarters, Washington, DC. https:// www.hq.nasa.gov/office/pao/History/taskgrp.html. Accessed 2 December 2020.

Spravka [Information]. 1972. 30 March. Fond 1678 (Interkosmos), opis' 1, delo 224в, ARAN.

Stenogramma zasedanya kollegii Ministerstva obshchego mashinostreniya [Stenographic record of a session of the Collegium of the Ministry of General Machine Bulding]. 1969. 8 May, 119-136. https ://www.roscosmos.ru/media/files/history/luna17lunohod/1969-05-08_mom-protokol-stenograf.pdf. Accessed 2 December 2020.

Stenogramma Zasedanya Prezidiuma Akademii nauk SSSR [Stenographic record of a session of the Presidium of the Academy of Sciences of the USSR]. 1972. 14 December. Fond 579 (Glavnoe 
upravlenie vneshnich sviazei Akademii nauk SSSR [Main Department on External Relations of the Academy of Sciences of the USSR]), opis' 13, delo 199, ARAN.

Transcript of the phone call between Glynn Lunney and Konstantin Bushuyev. 1974. 13 August. Fond 1678 (Interkosmos), opis' 1, delo 393, 126-130, ARAN.

U.S. Information Agency, Office of Research and Analysis. 1959. Impact of U.S. and Soviet space programs on world opinion, 7 July. U.S. President's Committee on Information Activities Abroad (Sprague Committee) Records, 1959-1961, box 6, A83-10. Dwight D. Eisenhower Library, Abilene, Kansas. NASA. https://history.nasa.gov/sputnik/july59.html. Accessed 2 December 2020.

Werron, Tobias. 2012. Worum konkurrieren Nationalstaaten? Zu Begriff und Geschichte der Konkurrenz um 'weiche' globale Güter. Zeitschrift für Soziologie 41: 338-355.

Werron, Tobias. 2014. On public forms of competition. Cultural Studies $\leftrightarrow$ Critical Methodologies 14: $62-76$.

Wolfe, Audra J. 2013. Competing with the Soviets: Science, technology, and the state in Cold War America. Baltimore: Johns Hopkins Univ. Press.

Wolff, Kurt H. (ed.). 1964. The sociology of Georg Simmel. New York: Free Press.

Publisher's Note Springer Nature remains neutral with regard to jurisdictional claims in published maps and institutional affiliations. 